\title{
Human feline oesophagus
}

\author{
Suheil Artul, ${ }^{1}$ Hani Abu Shkara, ${ }^{1}$ Rami Khoury, ${ }_{1}^{1}$ George Habib ${ }^{2}$
}

'Department of Radiology, EMMS Hospital, Bar Ilan University Faculty of Medicine, Nazareth, Israel

${ }^{2}$ EMMS Hospital, Bar Ilan University Faculty of Medicine, Nazareth, Israel

\section{Correspondence to}

Dr Suheil Artul,

suheil_artul@hotmail.com

Accepted 18 March 2014

\section{DESCRIPTION}

A 54-year-old woman was referred to our department for upper gastrointestinal (UGI) barium study because of heartburn story for 1 month before admission.

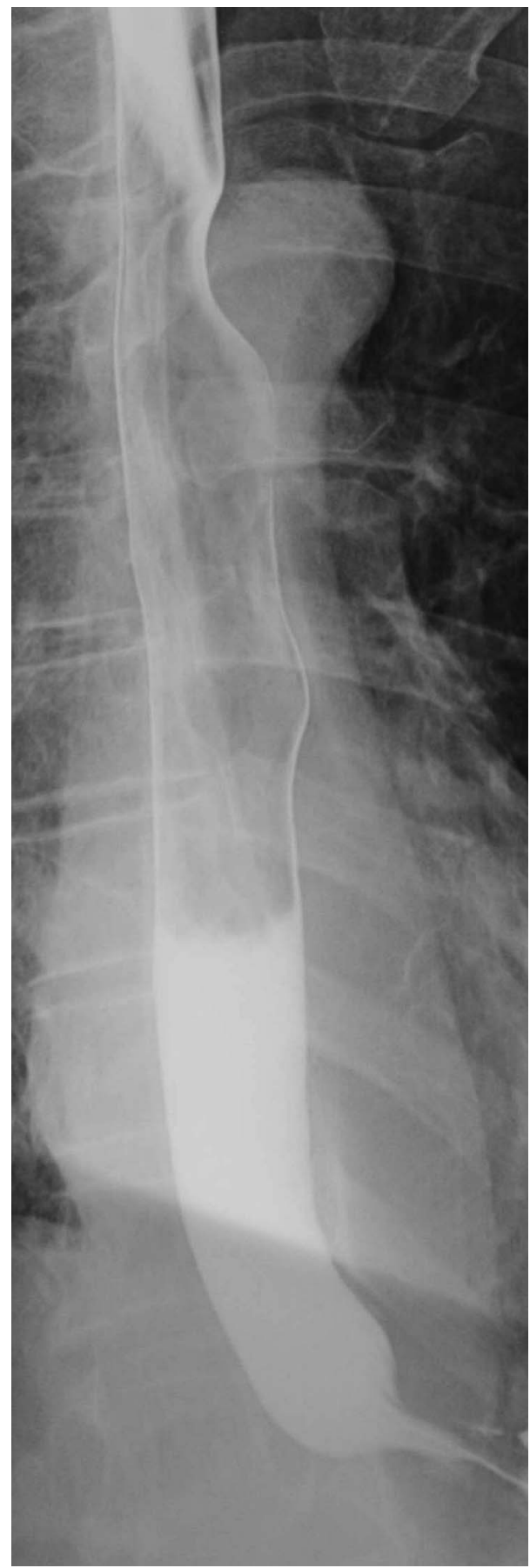

Figure 1 Upright left posterior oblique spot image during swallowing of barium showing normal mucosa of oesophagus.
Previous endoscopic upper gastro-oesophageal study revealed no pathology.

Upright UGI barium study was normal and showed normal mucosa of the oesophagus (figure 1) but in prone position we noticed: sliding hiatus hernia, gastro-oesophageal reflux (GER) and transient concentric rings of the distal oesophagus consistent of feline oesophagus (figure 2). The patient was treated successfully with antireflux therapy.

Transverse oesophageal folds were originally described in 1970 by Bremner et al as a normal anatomic feature of the cat oesophagus. These folds appear as thin 1-2 mm circular bands in UGI.

These transverse thin folds were radiologically described first by Goldberg as a normal finding on oesophagogram of cats. ${ }^{1}$

"Feline oesophagus" is a pathological finding in human oesophagogram.

In humans, feline oesophagus is usually a transient finding during reflux of barium and is a result of transient contraction of the longitudinally oriented muscularis mucosae secondary to increased intraoesophageal pressure. Feline oesophagus sign must be distinguished from the non-transient or fixed ring oesophageal appearance. Fixed rings are more than $2 \mathrm{~mm}$ thick, usually associated with reflux oesophagitis and strictures. ${ }^{2}$

Feline oesophagus is associated with GER, hiatus hernia and oesophageal motility disorders. In fact when this sign is present, the diagnosis of GER must be included even if GER itself is not seen clearly in the UGI barium study.

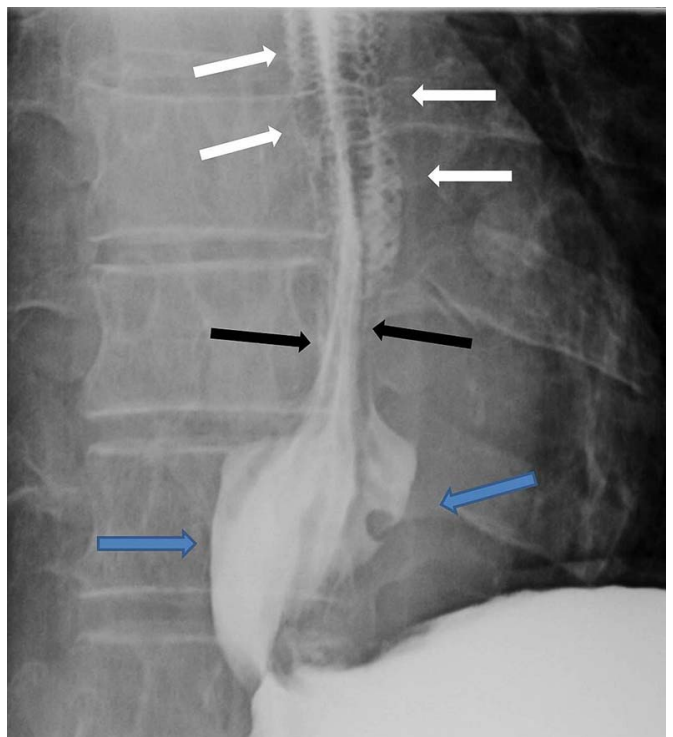

Figure 2 Prone right posterior oblique spot image from upper gastrointestinal study showing transient thin transverse striations 'white arrows' (feline oesophagus), hiatus hernia 'blue arrows' and gastro-oesophageal reflux 'black arrows'. 


\section{Learning points}

- Feline oesophagus is a transitory sign which must be distinguished from the fixed ring sign, the latter one is a sign of oesophagitis.

- When feline oesophagus is detected, the patient is extremely likely to have gastro-oesophageal reflux, hiatus hernia or oesophageal disorder motility.

- Patients with feline oesophagus usually will benefit from the treatment of antireflux.
Contributors SA diagnosed the case and the other authors assisted in writing and treating the patient.

Competing interests None.

Patient consent Obtained.

Provenance and peer review Not commissioned; externally peer reviewed.

\section{REFERENCES}

1 Samadi F, Levine MS, Rubesin SE, et al. Feline esophagus and gastroesophageal reflux. AJR Am J Roentgenol 2010;194:972-6.

2 Gohel VK, Edell SL, Laufer I, et al. Transverse folds in the human esophagus. Radiology 1978;128:303-8.

Copyright 2014 BMJ Publishing Group. All rights reserved. For permission to reuse any of this content visit http://group.bmj.com/group/rights-licensing/permissions.

BMJ Case Report Fellows may re-use this article for personal use and teaching without any further permission.

Become a Fellow of BMJ Case Reports today and you can:

- Submit as many cases as you like

- Enjoy fast sympathetic peer review and rapid publication of accepted articles

- Access all the published articles

- Re-use any of the published material for personal use and teaching without further permission

For information on Institutional Fellowships contact consortiasales@bmjgroup.com

Visit casereports.bmj.com for more articles like this and to become a Fellow 